\title{
Peranan Pendidikan Keluarga Tentang Kekudusan Hidup Menurut Roma 12:1-2
}

\author{
Widhi Arief Nugroho \\ 1) Dosen Sekolah Tinggi Teologi Tawangmangu \\ *) Penulis korespondensi: jeremyarif18@gmail.com
}

Received: 13 Dec 2018 / Revised: 22 Dec 2018 / Accepted: 26 Dec 2018

\begin{abstract}
Abstrak
Peran aktif keluarga dan orang tua merupakan sebuah usaha yang secara langsung dalam memberikan sosialisasi terhadap anak dan juga menciptakan lingkungan rumah dan gereja sebagai lingkungan sosial yang pertama dijumpai oleh anak. Anak menjadi hal terpenting yang harus diperhatikan oleh keluarga, dalam kehidupannya anak perlu mendapat perhatian khusus dari orang tua baik ayah mau pun ibu, hal itu dikarenakan keluarga merupakan tempat pertama yang menerima anak lahir didunia. Tidak hanya hal itu keluarga juga menjadi tempat bagaimana anak belajar dalam berkehidupan yaitu dari awal cara makan sampai anak belajar hidup dalam masyarakat. Dalam realita peneliti mengamati banyak terjadi seks bebas di kalangan remaja. Mereka menganggap bahwa seks bukanlah suatu yang tabu dan kudus.
\end{abstract}

Kata kunci: Pendidikan keluarga, kekudusan hidup, Surat Roma

\begin{abstract}
The active role of family and parents is a effort that directly provides socialization to children and also creates a home and church environment as the first social environment for children. Children become the most important thing that must be considered by the family, in their lives the child needs special attention from parents, both father and mother, because family is the first place to receive children born in the world. Not only is the
\end{abstract}


family a place where children learn to live, namely from the beginning of the way to eat until the child learns to live in the community. In reality researchers observe a lot of free sex among teenagers. They assume that sex is not a taboo and holy thing.

Keywords: Family education, life holiness, Romans

\section{Pendahuluan}

Pendidikan merupakan tanggung jawab bersama antara keluarga masyarakat dan pemerintah. Sehingga orang tua tidak boleh menganggap bahwa pendidikan anak hanyalah tanggung jawab sekolah.

Pendidikan merupakan suatu "usaha manusia untuk membentuk kepribadiannya agar sesuai dengan norma-norma atau aturan di masyarakat yang berlaku dengan baik"1. Setiap orang dewasa di dalam masyarakat dapat menjadi pendidik, sebab pendidik merupakan suatu perbuatan sosial yang mendasar untuk petumbuhan atau perkembangan anak didik menjadi manusia yang mampu berpikir dewasa dan bijak.

Orang tua sebagai lingkungan pertama dan utama dimana anak berinteraksi sebagai lembaga pendidikan yang tertua, artinya disinilah dimulai suatu proses pendidikan. Sehingga orang tua berperan sebagai pendidik bagi anak-anaknya. Lingkungan keluarga juga dikatakan lingkungan yang paling utama, karena sebagian besar kehidupan anak di dalam keluarga, sehingga pendidikan yang paling banyak diterima anak adalah dalam keluarga. Menurut Hasbullah (1997), dalam tulisannya tentang dasar-dasar ilmu pendidikan, bahwa "keluarga sebagai lembaga pendidikan memiliki beberapa fungsi yaitu fungsi dalam mengembangkan kepribadian anak dan mendidik anak dirumah; fungsi keluarga/orang tua dalam mensukseskan pendidikan di sekolah"2.

Fungsi keluarga dalam pembentukan kepribadian dan mendidik anak di rumah:

"sebagai pengalaman pertama masa kanak-kanak, menjamin kehidupan emosional anak, menanamkan dasar pendidikan moral anak memberikan dasar pendidikan sosial, meletakan dasar-dasar pendidikan agama, bertanggung jawab dalam

\footnotetext{
${ }^{1}$ Ahmad Tafsir. 2002. Pendidikan Agama Dalam Keluarga, (Bandung: Remaja rosdakarya) 8-9

${ }_{2}^{2}$ Hasbullah. 1994. Pendidikan dalam Keluarga (Jakarta: Rajawali Press), 9-10
} 
memotivasi dan mendorong keberhasilan anak, memberikan kesempatan belajar dengan mengenalkan berbagai ilmu pengetahuan dan keterampilan yang berguna bagi kehidupan kelak sehingga ia mampu menjadi manusia dewasa yang mandiri, menjaga kesehatan anak sehingga ia dapat dengan nyaman menjalankan proses belajar yang utuh, memberikan kebahagiaan dengan memberikan pendidikan agama sebagai tujuan akhir manusia". ${ }^{3}$

Dari keterangan di atas maka dapat ditarik kesimpulan bahwa keluarga merupakan tempat pendidikan pertama dan utama bagi anak-anak. Pada masa ini dengan berkembangnya teknologi dan era globalisasi maka semua lini dapat diakses dengan begitu mudahnya. Bahkan anak-anak usia sekolah sudah meninggalkan bentuk-bentuk permainan tradisional mereka dan beralih pada "gadget" mereka masing-masing. Internet telah menjadi suatu kebutuhan primer bagi mereka. Bergaul dengan jejaring sosial sudah sangat lekat dengan kehidupan mereka. Melalui hal ini pula tidak bisa dipungkiri bahwa telah terjadi dekadensi moral di kalangan pelajar.

Harus diakui putaran globalisasi yang begitu cepat menyebabkan tranformasi sosial berjalan mempesat. Pada kondisi ini perubahan diberbagai sektor tak ubahnya suatu keniscayaan yang tidak bisa dibendung. Diawali dari mempesatnya perkembangan teknologi, akses informasi yang kian mudah, ditambah lagi terbukanya proses akulturasi dan asimilasi budaya menyebabkan pelajar kita mudah terkontaminasi oleh arus globalisasai.

Pada batasan demikian, maka membentengi generasi muda dari segala keumungkinan yang mengancam eksistensi dan karakter diri mereka harus benar-benar diperhatikan. Bila tidak demikian, maka bukan tidak mungkin jika pada suatu saat nanti generasi kita akan dihadapkan pada krisis moral berkepanjangan.

Pendidikan pada dasarnya adalah proses memanusiakan manusia, mewujudkan pribadi-pribadi berahlak, bermoral, berperilaku baik. Berkuallitas serta memiliki integritas diri yang kuat. Bagi lembaga pendidikan, baik negeri maupun swasta memenuhi kriteria di muka adalah satu keniscayaan yang tidak boleh dikesampingkan. Karena demikian

\footnotetext{
${ }^{3}$ Langgulung, Hasan. 1995. Manusia \& Pendidikan : Suatu Analisa Psikologi \&Pendidikan (catatan ketiga),( Jakarta:Gramedia), 197
} 
merupakan amanat undang-undang yang harus dipenuhi, sebagaimana tercantum dalam UU No. 20 Tahun 2003 tentang sistem pendidikan Nasional Pada pasal 3 yang pada intinya "pendidikan ditujukan mewujudkan manusia berkualitas sekaligus barkarakter" .

Proses belajar mengajar keberhasilannya dipengaruhi oleh berbagai faktor. Menurut Slameto faktor intern adalah "faktor yang ada dalam diri individu, sedangkan faktor ekstern adalah faktor yang ada diluar individu" 5 .

Pendidikan keluarga adalah salah satu bentuk pendidikan di luar sekolah yang besar pengaruhnya terhadap keberhasilan siswa dalam belajar. Dan pendidikan keluarga yang maksimal, memiliki kecenderungan untuk meningkatkan minat siswa dalam belajar, yang pada akhirnya akan mempengaruhi pula terhadap belajar siswa. Sedangkan lemahnya pendidikan keluarga memiliki kecenderungan untuk melemahkan minat siswa dalam belajar dan akan melemahkan pula terhadap prestasi belajar siswa.

Keluarga merupakan bagian yang tidak dapat terpisahkan dalam kehidupan. Keluarga menjadi tempat pertama seseorang memulai kehidupannya. Keluarga membentuk suatu hubungan yang sangat erat antara ayah, ibu, maupun anak. (Hubungan tersebut terjadi dimana antar anggota). "Keluarga adalah unit terkecil dari masyarakat yang terdiri atas Kepala Keluarga dan beberapa orang yang berkumpul dan tinggal di suatu tempat dibawah suatu atap dalam keadaan saling ketergantungan"6.

Keluarga saling berinteraksi. Interaksi tersebut menjadikan suatu keakraban yang terjalin di dalam keluarga, dalam keadaan yang normal maka lingkungan yang pertama yang berhubungan dengan anak adalah orang tuanya, saudara- saudaranya serta mungkin kerabat dekatnya yang tinggal serumah. "Melalui lingkungan itulah anak mulai mengenal dunia sekitarnya dan pola pergaulan hidup yang berlaku sehari-hari; melaui lingkungan itulah anak mengalami proses sosialisasi awal" ${ }^{7}$. Keluarga sebagai institusi sosial terkecil, merupakan fondasi dan investasi awal untuk membangun kehidupan sosial dan kehidupan bermasyarakat secara luas menjadi lebih baik. Peran aktif orang tua merupakan sebuah usaha yang

\footnotetext{
${ }^{4}$ UU No. 20 Tahun 2003

${ }^{5}$ Slameto. 2003. Belajar dan Faktor-Faktor yang Mempengaruhinya (Jakarta: PT Rineka Cipta), 56

${ }^{6}$ Depkes RI, 1998

${ }^{7}$ Soekanto, Soerjono. 2004. Sosiologi Suatu Pengantar (Jakarta:Raja Grafindo
} Persada), 65 
secara langsung dalam memberikan sosialisasi terhadap anak dan juga menciptakan lingkungan rumah sebagai lingkungan sosial yang pertama dijumpai oleh anak. Anak menjadi hal terpenting yang harus diperhatikan oleh keluarga, dalam kehidupannya anak perlu mendapat perhatian khusus dari orang tua baik ayah maupun ibu, hal itu dikarenakan keluarga merupakan tempat pertama yang menerima anak lahir didunia.Tidak hanya hal itu "keluarga juga menjadi tempat bagaimana anak belajar dalam berkehidupan yaitu dari awal cara makan sampai anak belajar hidup dalam masyarakat". 8

Dalam realita peneliti mengamati banyak terjadi seks bebas di kalangan remaja. Mereka menganggap bahwa seks bukanlah suatu yang tabu dan kudus. Berganti- ganti pasangan dan lain sebagainya. Padahal dalam gereja sedang gencar-gencarnya memerangi seks bebas dengan cara memberikan seminar tentang bahayanya seks bebas. Dan tidak hanya gereja, keluargapun juga memberikan pendidikan bahayanya seks bebas. Namun hasilnya masih belum maksimal.

$\underline{\text { Roma 12:1 }}$

${ }^{\mathrm{KJV}}$ Romans 12:1 I beseech you therefore, brethren, by the mercies of God, that ye present your bodies a living sacrifice, holy, acceptable unto God, which is your reasonable service. ${ }^{9}$

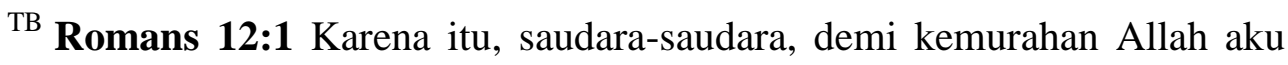
menasihatkan kamu, supaya kamu mempersembahkan tubuhmu sebagai persembahan yang hidup, yang kudus dan yang berkenan kepada Allah: itu adalah ibadahmu yang sejati. ${ }^{10}$

Ajakan dan ajaran Paulus mengenai kehidupan Kristen dibukanya dengan berkata: "saudara-saudara... aku menasihatkan kamu ..." Kata-kata pembukaan Paulus dalam Roma 12:1 dalah suatu peristiwa bila ia mulai membicarakan perkara yang dianggapnya penting. Menyusullah isi nasihat Paulus: "supaya kamu mempersembahkan tubuhmu sebagai persembahan yang hidup".Yang dalam bahasa Yunani adalah parasth/sai ta.sw,mata

\footnotetext{
${ }^{8}$ Helvie C.O. 1998. Advanced Practice Nursing in The Community (California: Sage publication Inc), 89

${ }^{9}$ Ibid

${ }^{10}$ Alkitab. 2006. Lembaga Alkitab Indonesia.
} 
u`mw/n qusi,an zw/san((parastemi ta somata humon thusian zaoan). Kata mempersembahkan parasth/sai(parastemi) merupakan bentuk verb infinitive aorist active dari pari,sthm. . Di ayat ini parasth/sai(parastemi) merupakan istilah peribadatan dari lingkungan bait Allah: mempersembahkan (kurban). Artinya itu ditegaskan oleh pemakaian 'persembahan' (kurban).Yang harus dipersembahkan kepada Allah itu ialah tubuhmu. Jadi, 'persembahan yang hidup' adalah penyerahan diri kita untuk menempuh kehidupan baru, yang menjauhi dosa dan menentang kuasa dosa itu.

Persembahan itu disebut juga kudus. Dengan demikian diungkapkan bahwa 'tubuh (= kehidupan) kita bukan lagi milik kita sendiri. Sebab 'mempersembahkan kurban' berarti kurban itu diserahkan menjadi milik Allah.Maka, kalau orang percaya 'mempersembahkan tubuhnya' kepada Allah, hal itu berarti bahwa seluruh kehidupan mereka adalah milik Tuhan. Untuk seterusnya mereka harus minta kepada-Nya apa kehendak-Nya mengenai kehidupan mereka. Dengan demikian perkataan ' kudus' itu mencakup pula arti ' suci'. Seorang Kristen harus berupaya terus hidup semakin sesuai dengan kehendak Dia yang menjadi pemiliknya, tuannya.Dengan demikian juga persembahannya menjadi berkenan kepada Allah.

Akhirnya Paulus menulis: "itu adalah ibadahmu yang sejati."

Roma 12:2

Romans 12:2 And be not conformed to this world: but be ye transformed by the renewing of your mind, that ye may prove what is that good, and acceptable, and perfect, will of God. ${ }^{11}$

${ }_{\text {ITB }}$ Romans 12:2 Janganlah kamu menjadi serupa dengan dunia ini, tetapi berubahlah oleh pembaharuan budimu, sehingga kamu dapat membedakan manakah kehendak Allah: apa yang baik, yang berkenan kepada Allah dan yang sempurna. ${ }^{12}$

\section{Ayat 2:}

'Persembahan tubuh' dan' ibadah' yang disebut dalam ayat 1 memiliki segi negatif dan segi positif.Segi negatifnya ialah orang Kristen tidak boleh lagi membiarkan pola hidup mereka ditentukan oleh dunia. Menurut terjemahan harfiah: 'jangan lagi biarkan dirimu menjadi sepola

\footnotetext{
${ }^{11}$ Ibid

${ }^{12}$ Alkitab.2006. Lembaga Alkitab Indonesia.
} 
dengan dunia ini'. Artinya 'masa yang sangat panjang', 'masa hidup dunia'; dari situ 'dunia', bandingkan misalnya 1 Korintus 1:20 dan 2:6. Dilihat dari segi positif, anjuran Paulus berbunyi: 'berubahlah oleh pembaharuan budimu'. Perubahan itu berlangsung oleh pembaharuan budimu. Sepertinya di sini 'budi' dipilih karena dalam hubungan ini artinya memang perubahan kelakuan manusia.bukan perubahan pikirannya saja, Yang dimaksud ialah pusat kemauan kita, yang mengambil keputusan-keputusan yang menentukan tindakan kita (bandingkan Amsal 4:23). Pusat itu perlu dibarui.Telah kita lihat bahwa pembaruan hidup dikerjakan oleh Roh Kudus (7:6; 8:4).Namun, di sini manusia sendiri juga diajak membarui diri.

Bagian kedua ayat ini menyebut hasil pembaruan budi.Tujuannya ialah sehingga kamu dapat membedakan manakah kehendak Allah. Kata kerja Yunani (dokimazein) berarti: memeriksa, menguji. Ternyata kehendak Allah tidak dengan sendirinya jelas, karena dua alasan: Pertama, karena dalam kehidupan sehari-hari seorang Kristen dihadapkan dengan berbagai keadaan. Sering sulit baginya untuk begitu saja menentukan sikapnya. Apalagi pada masa kini, dengan perkembangan teknologi yang cepat di berbagai bidang, orang Kristen tidak begitu saja dapat menentukan apakah la boleh menggunakan anekaragam sarana mutakhir. Kita dapat membayangkan perkembangan di bidang medis, atau di bidang teknologi nuklir (masih terlepas dari soal persenjataan). Dalam semua hal itu diperlukan penimbangan matang sebelum kita dapat menentukan (itu pun dengan hati-hatil) manakah kehendak Allah.

Kedua, manusia diajak mengusahakan 'budi' kita dalam mencari kehendak Allah, karena Alkitab bukanlah kitab hukum.Alkitab tidak menyajikan kepada kita seperangkat peraturan yang menunjuk jalan kepada orang Kristen sekaligus mengikat mereka. Sebab Injil tidak merupakan hukum yang haru, tetapi justru memberi kita kebebasan anak-anak Allah (Roma 8:15,21).Dalam Alkitab mencatat lagi bahwa anjuran ini diarahkan oleh Paulus kepada setiap anggota jemaat di Roma (bandingkan ayat 3).Jadi, kita boleh menganggapnya diarahkan kepada setiap orang Kristen. Bukan pendeta, atau penatua, atau sinode, atau uskup, yang harus menentukan 'manakah kehendak Allah', lalu menurunkan keputusannya ke jemaat. Anggota-anggota jemaat tidak boleh malas menunggu petunjuk 'dari atas'. Setiap orang percaya dipanggil dan diperbolehkan mempertimbangkan sendiri kehendak Allah. 
Hanya, dengan demikian kita tidak boleh mengabaikan seginya yang lain, yaitu bahwa anjuran ini diarahkan oleh Paulus kepada setiap anggota jemaat di Roma.Orang-orang Kristen bukan individu-individu yang hidup sendiri-sendiri. Mereka merupakan satu tubuh (ayat 4!). Maka dalam mencari kehendak Allah pun mereka akan berkumpul, dan saling meminta nasihat. Itulah juga antara lain makna sidang majelis dan sidang sinode. Tinggal kita tafsirkan tiga kata yang dipakai Paulus umuk merinci kehendak Allah: apa yang baik, yang berkenan kepada Allah dan yang sempurna. Mungkin kita anggap luapan kata-kata ini agak berlebihan.Tetapi agaknya dalam jemaat Roma ada yang cenderung mengutamakan kebebasan orang percaya tersebut di alas begitu rupa, sehingga mereka tidak mau lagi terikat pada aturan aturan bagi kelakuan mereka Berhadapan dengan orang seperti itu perlu dipentingkan bahwa melakukan kehendak Allah adalah melakukan 'yang baik'. Dari Galatia 6:10 dan I Tesalonika 5: 15 kita tahu bahwa 'yang baik ' itu ialah perbuatan yang sederhana dan sangat konkret: menolong orang yang berkebutuhan, mengampuni mereka yang bersalah kepada kita.

Pendidikan dalam keluarga merupakan hal yang sangat esensi. Dari segi etimologis, pendidikan berasal dari bahasa Yunani "Paedagogike". Ini adalah kata majemuk yang terdiri dari kata "Pais" yang berarti "Anak" dan kata "Ago" yang berarti "Aku membimbing". Jadi "Paedagogike" berarti aku membimbing anak ${ }^{13}$. Sedangkan Hasabullah, menyatakan bahwa "pendidikan berarti bimbingan atau pertolongan yang diberikan dengan sengaja oleh orang dewasa agar ia menjadi dewasa"14. Dengan demikian dapat disimpulkan bahwa pendidikan merupakan usaha sadar dan terencana untuk mendewasakan peserta didik.

Keluarga menurut Siti Partini "adalah sekelompok manusia yang terdiri atas suami, istri, anak-anak (bila ada) yang terikat atau didahului dengan perkawinan" ${ }^{15}$. Sedangkan Khairudin H.SS, menyatakan bahwa keluarga adalah susunan orang-orang yang disatukan oleh ikatan-ikatan perkawinan, darah atau adopsi, pertalian antara suami istri adalah

${ }^{13}$ Soedomo, A. Hadi. 2008. Pendidikan: Suatu pengantar (Surakarta: UNS Press), 17

${ }^{14}$ Hasbullah. 2009. Dasar-Dasar Ilmu Pendidikan (Jakarta: Penerbit Bumi Persada), 1

${ }^{15}$ Siti Partini Suardiman. 2003. Metode Pengembangan Daya Pikir dan Daya Cipta untuk Anak Usia Dini (Yogyakarta: FIP UNY), 81 
perkawinan dan hubungan antara orang tua dan anak biasanya adalah darah dan kadang kala adopsi. ${ }^{16}$

Dari pendapat di atas dapat disimpulkan bahwa keluarga merupakan suatu ikatan yang didasari perkawinan. Keluarga bisa saja dengan mempunyai anak sendiri ataupun adopsi, bisa juga tanpa anak.

Pendidikan yang terjadi di rumah tangga/ di lingkungan keluarga (termasuk pendidikan informal). Pendidikan informal adalah proses pendidikan yang diperoleh seseorang dari pengalaman sehari-hari dengan sadar atau tidak sadar, pada umumnya tidak teratur dan tidak sistematis, sejak orang lahir sampai mati, seperti di dalam keluarga, tetangga, pekerjaan, hiburan, pasar, atau di dalam pergaulan sehari-hari. Pendidikan dalam "keluarga adalah pendidikan yang pertama dan utama bagi setiap manusia. Seseorang lebih banyak berada dalam rumah tangga dibandingkan dengan di tempat-tempat lain ${ }^{17}$.

Dari pengertian diatas maka dapat ditarik kesimpulan bahwa walaupun pendidikan keluarga tergolong pendidikan informal, namun pendidikan itulah yang di alami semua anak pada waktu pertama kali, oleh sebab itu sangatlah penting pendidikan keluarga ini.

Pendidik merupakan salah satu faktor pendidikan yang sangat penting, karena pendidik itulah yang bertanggung jawab dalam membimbing dan membentuk pribadi anak didiknya. Dalam keluarga orang tua berperan sebagai pendidik, sehingga sikap dan tindakannya sehari-hari memberi stimulus terhadap tingkah laku anak. Kesalahan-kesalahan orang tua dalam mendidik anak dapat mengakibatkan anak dalam perkembangannya tidak mampu mandiri dan sulit menyesuaikan diri dengan lingkungan. Anak mendapat rangsangan maupun hambatan dalam pertumbuhan dan perkembangan, mulai mengenal masyarakat sekitarnya, mempelajari norma dan aturan-aturan permainan hidup dalam masyarakat dari orang tua. Anak tidak saja mengenal tetapi dilatih menghargai dan mengikuti norma-norma dan aturan hidup bermasyarakat lewat kehidupan keluarga.

\footnotetext{
${ }^{16}$ Khairudin, H, HSS. 1997. Sosiologi Keluarga (Yogyakarta : Liberty press), 71

${ }^{17}$ Philip H. Coombs. 1982. Apakah Perencanaan Pendidikan Itu, (terjemah)

(Jakarta: Bhatara Karya Akasara),1 58
} 
Fungsi pendidikan di dalam keluarga harus dimaksimalkan. Lingkungan keluarga merupakan lingkungan pendidikan yang pertama, karena dalam keluarga inilah anak pertama-tama mendapatkan didikan dan bimbingan. Juga dikatakan lingkungan yang utama, karena sebagian besar dari kehidupan anak adalah di dalam keluarga, sehingga pendidikan yang paling banyak diterima oleh anak adalah dalam keluaga.

Tugas utama dari keluarga bagi pendidikan anak adalah sebagai peletak dasar bagi pendidikan akhlak dan pandangan hidup keagamaan.Sifat dan tabiat anak sebagian besar diambil dari kedua orang tuanya dan dari anggota kelurga yang lain.

Bagi seorang anak keluarga merupakan persekutuan hidup pada lingkungan keluarga tempat di mana dia menjadi diri pribadi atau diri sendiri. Keluarga juga merupakan wadah bagi anak dalam konteks proses belajarnya untuk mengembangkan dan membentuk diri dalam fungsi sosialnya. Disamping itu keluarga merupakan tempat belajar bagi anak dalam segala sikap untuk berbakti kepada Tuhan sebagai perwujudan nilai hidup yang tertinggi. Dengan demikian jelaslah bahwa orang yang pertama dan utama bertanggung jawab terhadap kelangsungan hidup dan pendidikan anak adalah orang tua.

Terbentuknya sebuah keluarga tentunya ada tujuannya. Menurut Ihsan , beberapa fungsi lembaga pendidikan keluarga yaitu:

Merupakan pengalaman pertama bagi masa kanak-kanak, pengalaman ini merupakan faktor yang sangat penting bagi perkembangan berikutnya, khususnya dalam pengetahuan pribadinya.b Pendidikan di lingkungan keluarga dapat menjamin kehidupan emosional anak untuk tumbuh dan berkembang.Kehidupan emosional ini sangat penting dalam pembentukan pribadi anak.c. Di dalam keluarga akan terbentuk pendidikan moral. Keteladanan orang tua di dalam bertutur kata dan berprilaku sehari-hari akan menjadi wahana pendidikan moral bagi anak di dalam keluarga tersebut, guna membentuk manusia susila.d. Di dalam keluarga akan tumbuh sikap tolong menolong/ tenggang rasa sehingga tumbuhlah keluarga yang damai dan sejahtera. e. Keluarga merupakan lembaga yang memang berperan dalam meletakan dasar-dasar pendidikan agama.f. Di dalam konteks membangun anak sebagai makhluk individu diarahkan agar anak dapat 
mengembangkan dan menolong dirinya sendiri. Dalam kontek ini keluarga cenderung untuk menciptakan kondisi yang dapat menumbuhkan perkembangan inisiatif, kreativitas, kehendak, emosi, tanggungjawab, ketrampilan dan kegiatan lain sesuai dengan yang ada dalam keluarga. ${ }^{18}$

Dengan demikian terbentuknya keluarga adalah tidaklah kebetulan, melainkan memiliki fungsi dan tujuan yaitu untuk mendidik anak kepada suatu hal yang baik.

Keluarga merupakan suatu kesatuan hidup (sistem sosial), namun setiap anggota keluarga memiliki peran masing-masing. Pemaparan secara detail mengenai peran anggota keluarga adalah sebagai berikut: Peran ibu dalam pendidikan anak-anaknya adalah sebagai berikut: a. Sumber dan pemberi rasa kasih sayang, b. Pengasuh dan pemelihara, c. Pengatur kehidupan dalam rumah tangga, d. Pendidik dalam segi-segi emosional ${ }^{19}$

Dari pendapat tersebut tidak ada perbedaan tetapi saling melengkapi.Ibu sebagai istri dan teman hidup harus bisa mendampingi suami dalam keadaan apapun seperti mengatur kehidupan rumah tangga. Sebagai ibu dari anak-anak dan pendidik, maka ia harus mengasuh dan memelihara serta memberi rasa kasih sayang kepada anak-anaknya. Ibu merupakan pendidik dari segi emosional. Ditinjau dari fungsi dan tugasnya sebagai ayah, maka dapat dikemukakan bahwa peran ayah dalam mendidik anak yang lebih dominan adalah: a. "Sebagai sumber kekuasaan di dalam keluarga. b. Pelindung terhadap ancaman dari luar. c. Pendidik dari segi rasional",20

Menurut salim, menjelaskan bahwa peran ayah terdiri dari: a. Pemimpin keluarga.

b. Pencari nafkah. c. Pendidik anak-anak. d. Membantu mengurus rumah tangga. $^{21}$

Selain oleh ibu dan ayah, banyak pula anak-anak yang menerima pendidikan dari nenek atau kakek atau keduanya.“

\footnotetext{
${ }^{18}$ Fuad Ihsan. 2005. Perkembangan Peserta Didik. (Jakarta: Rineka Cipta), 18-19

${ }^{19}$ Ngalim Purwanto. 1992. Prinsip-prinsip dan Teknik Evaluasi Pembelajaran (Bandung: Remaja Rosdakarya), 82

${ }^{20}$ Purwanto. 2011. Evaluasi Hasil Belajar,(Yogyakarta : Pustaka Pelajar), 83

${ }^{21}$ Agus, Salim. 2006. Teori dan Paradigma Penelitian Sosial. (Yogyakarta: Tiara Wacana), 58
} 
Umumnya nenek atau kakek mencurahkan kasih sayang yang berlebih-lebihan kepada cucu-cucunya. Mereka tidak mengharapkan sesuatu dari cucunya, mereka semata-mata hanya memberi, oleh sebab itu kebanyakan nenek atau kakek akan memanjakan cucucucunya dengan berlebihan ${ }^{22}$.

Berpijak pada pengalaman tersebut, maka demi kepentingan anak, ada baiknya orangtua anak tidak hidup serumah dengan nenek dan kakeknya.Untuk memberikan kasih sayang dan menyenangkan cucucucunya cukup dengan kunjungan nenek dan kakek dalam waktu tertentu.

Keluarga yang berkecukupan ekonominya sering kali memiliki seorang atau lebih pembantu rumah tangga.Tugas pekerjaan pembantu rumah tangga, disamping membantu mengerjakan pekerjaan rumah tangga seperti memasak, mencuci, menyetrika pakaian, bersih-bersih dan sebagainya, sering pula diserahi mengasuh dan memelihara anak.Bahkan ada pula pembantu rumah tangga yang khusus diserahi tugas untuk mengasuh dan memelihara anak-anak yang masih kecil (babysitter), karena kedua orangtua anak-anak sibuk bekerja di luar rumah.Dalam hal demikian, "pembantu rumah tangga dapat dikatakan termasuk anggota keluarga yang juga turut berperan dalam pendidikan anak-anak di dalam keluarga"23.

Pada umumnya pembantu rumah tangga (yang bukan babysitter) tidak memiliki pengetahuan ataupun pengalaman yang cukup dalam hal mendidik atau mengasuh anak-anak, apalagi pembantu rumah tangga yang masih muda atau belum berumah tangga. Oleh karena itu, bagi orangtua betapapun sibuk dan terbatasnya waktu yang ada, tidak baik jika menyerahkan sepenuhnya pendidikan anak-anaknya kepada pembantu rumah tangga.

Peranan pembantu rumah tangga sebaiknya sebatas "pembantu" dalam mengasuh dan mendidik anak-anak di dalam keluarga.Sedangkan yang tetap berperan dalam menentukan pendidikan anak-anak adalah orang tua yaitu ayah dan ibu.

Nilai-Nilai Pendidikan dalam Lingkungan Keluarga sangat pwenting dalam hal ini. Bertens berpendapat nilai adalah "sesuatu yang menarik bagi manusia, sesuatu yang dicari, sesuatu yang menyenangkan, sesuatu yang

\footnotetext{
${ }^{22}$ Purwanto. 2011. Evaluasi Hasil Belajar (Yogyakarta : Pustaka Pelajar), 83

${ }^{23}$ Ibid. 84
} 
disukai dan diinginkan" ${ }^{24}$.Sedangkan menurut Kaelan nilai adalah "sifat atau kualitas yang melekat pada suatu objek, bukan objek itu sendiri. ${ }^{25}$ Sesuatu itu mengandung nilai artinya ada sifat atau kualitas yang melekat pada sesuatu itu.Kesimpulannya nilai adalah sesuatu yang penting berupa sifat atau kualitas yang melekat pada suatu objek.

Dalam keluarga diberikan bermacam-macam kemampuan, jika diperhatikan kegiatan di dalam rumah tangga terjadi transformasi nilai-nilai yang beraneka ragam. Anak laki-laki bersama-sama ayahnya mencuci sepeda motor, memperbaiki sesuatu di rumah, ia bersama-sama berdoa dengan ayahnya di rumah atau di gereja. Anak putri bersama ibu membantu memasak, mengatur tempat tidur, menyapu dan sebagainya. Fenomena kehidupan ini dapat dilihat sebagai suatu proses kegiatan mendidik.

Dari semua aspek dalam mengasuh anak, tidak ada bagian yang sama pentingnya dengan membesarkan anak dengan nilai-nilai yang luhur/ baik. Linda dan Richard Eyre (dalam Nugroho : 2008), membagi nilai yang dapat diajarkan orangtua kepada anak menjadi dua yaitu ${ }^{26}$ :

Nilai Nurani

Haryono memberikan pendapat Nurani adalah "hati nurani atau hati.Dengan demikian nilai nurani merupakan nilai yang bersumber dari hati nurani seseorang" ${ }^{27}$.Purwanto, menggunakan istilah lain untuk menyebut nurani yaitu kesusilaan. "Maksud dan tujuan kesusilaan adalah memimpin anak setia serta mengerjakan segala sesuatu yang baik, dan meninggalkan yang buruk atas kemauan sendiri dalam segala hal dan setiap waktu" ${ }^{28}$.Nilai nurani terdiri dari kejujuran, keberanian, cinta damai, disiplin diri, dan kemurnian dan kesucian.

Kejujuran,Jujur adalah "perilaku yang didasarkan pada upaya menjadikan dirinya sebagai orang yang selalu dapat dipercaya dalam perkataan, tindakan, dan pekerjaan" ${ }^{29}$.Sedangkan menurut Zuriah "jujur

\footnotetext{
${ }^{24}$ Bertens, K. 1989. Etika dan Etiket, Pentingya Sebuah Perbedaan, (Yogyakarta: Kanisius), 139

${ }^{25}$ Kaelan. 2004. Pendidikan Pancasila Edisi Reformasi (Yogyakarta:Gramedia), 174

${ }^{26}$ Linda \& Richard Eyre. 1997. Mengajarkan Nilai-nilai Kepada Anak, (Jakarta : Gramedia PustakaUtama), 68

${ }^{27}$ Umar, Haryono, dkk. 2004. Akuntabilitas Konsep Dan Pengukuran, (Jakarta: Penerbit Universitas Trisakti), 609

${ }^{28}$ Purwanto. 2011. Evaluasi Hasil Belajar (Yogyakarta: Pustaka Pelajar), 158

${ }^{29}$ Ibid. Haryono, 399
} 
merupakan sikap atau perilaku yang tidak suka berbohong dan berbuat curang, berkata apa adanya, dan berani mengakui kesalahan" ${ }^{30}$.Dalam pandangan umum, kata jujur sering dimaknai adanya kesamaan antara realitas (kenyataan) dengan ucapan, dengan kata lain apa adanya.

\section{Kesimpulan}

Peranan Pendidikan keluarga sangat penting untuk memberikan pengertian kepada anggota keluarga, khususnya kepada anak-anak agar senantiasa menjada kekudusan. Pendidikan seks bukanlah hal yang tabu, namun hendaknya dapat menjadi acuan agar lebih hati-hati dalam bertindak. Keteladanan orang tua mempunyai peran penting dalam hal ini. Orang tua harus mendidik anak-anak serta seluruh anggota keluarga untuk dapat hidup dalam kekudusan sesuai dengan Roma 12:1-2. Setiap anggota keluarga hendaknya mengalami pembaharuan budi, artinya mengalami perubahan menuju ke arah yang lebih baik lagi.

Lingkungan juga sangat mempengaruhi kehidupan rohani seseorang. Rasul Paulus juga menyatakan bahwa pergaulan yang buruk merusakkan kebiasaan yang baik. Jadi di dalam keluarga harus diciptakan suasana yang kondusif dan hal itu dapat tercapai saat anggota keluarganya hidup di dalam kekudusan serta mendasarkan keluarga tersebut pada ibadah yang sejati.

Peran setiap anggota keluarga sangat penting. Seluruh anggota keluarga berperan seperti sebuah team work untuk membangun atmosfer keluarga yang baik dan nyaman. Sehingga rumah menjadi tempat yang terbaik untuk dapat berbagi dan saling menguatkan. Hal ini akan meminimalisir terjadinya gangguan atau hal-hal yang negatif di dalam keluarga tersebut. Saat keluarga kuat di dalam membangun ibadah serta komunikasi yang sehat, maka keluarga tersebut akan menjadi keluarga yang baik dan saling mendukung.

\section{Kepustakaan}

Agus, Salim. 2006. Teori dan Paradigma Penelitian Sosial. Yogyakarta: Tiara Wacana.

Alkitab, Lembaga Alkitab Indonesia.

\footnotetext{
${ }^{30}$ Nurul Zuriah. 2006. Metedologi Penelitian Sosial Dan Pendidikan (Teori Aplikasi).( Jakarta : PT Bumi Aksara), 83
} 
Bertens, K. 1989. Etika dan Etiket, Pentingya Sebuah Perbedaan. Yogyakarta: Kanisius.

BibleWork 7, Roma 12:2

Ahmad Tafsir. 2002. Pendidikan Agama Dalam Keluarga. Bandung: Remaja rosdakarya.

Fuad Ihsan. 2005. Perkembangan Peserta Didik. Jakarta: Rineka Cipta. Haryono, dkk. 2007. Akuntabilitas Konsep Dan Pengukuran. Jakarta: Penerbit Universitas Trisakti.

Hasbullah, 1994. Pendidikan dalam Keluarga. Jakarta: Rajawali Press. . 2009. Dasar-Dasar Ilmu Pendidikan. Jakarta: Penerbit Bumi Persada.

Helvie C.O. 1998. Advanced Practice Nursing in The Community. California: Sage publication Inc.

Kaelan. 2004. Pendidikan Pancasila Edisi Reformasi.

Yogyakarta:Gramedia.

Khairudin, H, HSS, 1997. Sosiologi Keluarga. Yogyakarta : Liberty press.

Langgulung, Hasan. 1995. Manusia \& Pendidikan : Suatu Analisa Psikologi

\&Pendidikan (catatan ketiga). Jakarta:Gramedia.

Linda \& Richard Eyre. 1997. Mengajarkan Nilai-nilai Kepada Anak. Jakarta : Gramedia PustakaUtama.

Ngalim Purwanto. 1992. Prinsip-prinsip dan Teknik Evaluasi Pembelajaran. Bandung: Remaja Rosdakarya.

Nurul Zuriah. 2006. Metedologi Penelitian Sosial Dan Pendidikan (Teori Aplikasi). Jakarta : PT Bumi Aksara.

Philip H. Coombs. 1982. Apakah Perencanaan Pendidikan Itu, (terjemah). Jakarta: Bhatara Karya Akasara.

Purwanto. 2011. Evaluasi Hasil Belajar. Yogyakarta : Pustaka Pelajar.

Siti Partini Suardiman. 2003. Metode Pengembangan Daya Pikir dan Daya Cipta untuk Anak Usia Dini. Yogyakarta: FIP UNY.

Soedomo, A. Hadi. 2008. Pendidikan: Suatu pengantar. Surakarta: UNS Press.

Soekanto, Soerjono. 2004. Sosiologi Suatu Pengantar. Jakarta:Raja Grafindo Persada.

Slameto. 2003. Belajar dan Faktor-Faktor yang Mempengaruhinya. Jakarta: PT Rineka Cipta.

Umar, Haryono, dkk. 2004. Akuntabilitas Konsep Dan Pengukuran. Jakarta: Penerbit Universitas Trisakti. 